\title{
Prevalence and Determinants of Hyperuricemia in Type 2 Diabetes Mellitus Patients Attending Jimma Medical Center, Southwestern Ethiopia, 2019
}

This article was published in the following Dove Press journal: Diabetes, Metabolic Syndrome and Obesity: Targets and Therapy

\section{Kumsa Kene Arersa (D) \\ Tesaka Wondimnew Mengistu Welde Tigist Mateos Husen}

Department of Biomedical Sciences, Division of Biochemistry, Jimma University, Institute of Health Sciences, Jimma, Ethiopia
Correspondence: Kumsa Kene Arersa Tel +25I-92I-593136

Email kumsa26@gmail.com
Objective: To assess the prevalence and determinants of hyperuricemia among type 2 diabetic patients on follow-up at Jimma Medical Center from March 1 to June 30, 2019.

Methods: This institution-based cross-sectional study was used to assess the level of serum uric acid in type 2 diabetic patients attending their follow-up at Jimma Medical Center chronic illness clinic. A systematic sampling technique was used to include 287 type 2 diabetic patients in the study and an interviewer-based questionnaire was used to collect important data from each participant. Five milliliters of blood were collected from each participant under sterile conditions and serum was separated by centrifugation at $3000 \mathrm{rpm}$ for 10 minutes. Serum was stored at $-20^{\circ} \mathrm{C}$ and analyzed for serum uric acid using an $\mathrm{ABX}$ Pentra 400 clinical chemistry analyzer. Bivariate and multivariable binary logistic regression were used to assess significant associations between hyperuricemia and independent factors. A $p$-value of $<0.05$ was considered significant in the final model.

Results: The mean \pm SD age of the study participants was $51.79 \pm 14.36$ years. The prevalence of hyperuricemia was found to be $22 \%(n=66 / 287)$ in the study population. Hyperuricemia was common in those aged $\geq 60$ years and males. Obesity (AOR=7.84, 95\% $\mathrm{CI}=2.005-30.666$ ), duration of diabetes mellitus $(\mathrm{DM}) \geq 10$ years ( $\mathrm{AOR}=3.963,95 \%$ $\mathrm{CI}=1.902-8.259$ ), family history of $\mathrm{CVD}(\mathrm{AOR}=2.929,95 \% \mathrm{CI}=1.124-7.630)$, alcohol drinking $(\mathrm{AOR}=5.83,95 \% \mathrm{CI}=2.341-14.545)$ and increased $\mathrm{DBP} \quad(\mathrm{AOR}=4.198,95 \%$ $\mathrm{CI}=1.772-9.949$ ) were determinant variables for hyperuricemia in type $2 \mathrm{DM}$.

Conclusion: Hyperuricemia was relatively common among type 2 diabetic patients. The prevalence of hyperuricemia was common among patients with obesity, a long duration of $\mathrm{DM}$ and increased diastolic blood pressure, and alcohol drinkers. There is a need to raise awareness of lifestyle modification, healthy behavior and early diagnosis of hyperuricemia in type 2 diabetic patients.

Keywords: hyperuricemia, type 2 diabetes mellitus, Jimma University, Ethiopia

\section{Introduction}

Diabetes mellitus (DM) is a heterogeneous disturbance of metabolism, the main result of which is chronic hyperglycemia. It is caused by either impaired insulin secretion or impaired insulin action, or both. ${ }^{1}$ According to the World Health Organization (WHO) 2006, diagnostic criteria for DM are fasting plasma glucose $\geq 126 \mathrm{mg} / \mathrm{dL}(7.0 \mathrm{mmol} / \mathrm{L}), 2$-hour plasma glucose $\geq 11.1 \mathrm{mmol} / \mathrm{L}(200 \mathrm{mg} / \mathrm{dL})$ or glycated hemoglobin $\mathrm{A}_{1 \mathrm{C}}\left(\mathrm{HbA}_{1 \mathrm{C}}\right) \geq 6.5 \%{ }^{2}$ Type 2 diabetes mellitus (T2DM) is the most common form of DM, accounting for $90-95 \%$ of cases. ${ }^{1}$ T2DM is characterized by hyperglycemia, insulin resistance and relative insulin deficiency. ${ }^{3}$ The 
chronic hyperglycemia of diabetes causes significant longterm effects on various organs, such as the heart, kidneys, eyes, nerves and blood vessels. ${ }^{4}$ T2DM is caused by a combination of genetic factors related to impaired insulin secretion, insulin resistance and environmental factors, such as obesity, overeating, physical inactivity, stress and aging. ${ }^{5}$

Uric acid (UA) is the end product of purine catabolism. ${ }^{6}$ Hyperuricemia is an increase in serum UA caused by increased production or decreased excretion of UA, and also a combination of both. ${ }^{7}$ Humans are exposed to higher serum UA than other mammals because of an absence of urate oxidase due to a gene mutation that converts UA to allantoin. ${ }^{8}$ Hyperuricemia has been associated with dysglycemia, dyslipidemia, central obesity and hypertension. ${ }^{9}$ UA acts as a pro- oxidant, particularly at increased concentrations, and a marker of oxidative stress. ${ }^{10}$ As a result of insulin resistance, there is a decrease in excretion of UA due to the reduced effects of insulin. ${ }^{11} \mathrm{UA}$ is considered as one of the antioxidants that contribute to the prevention of atherosclerosis in its early stages. However, during later stages of atherosclerosis, when the UA level is elevated, it acts as a pro-oxidant rather than an antioxidant. ${ }^{12}$ Increased activity of the hexose monophosphate (HMP) shunt linked to insulin resistance causes hyperuricemia in diabetic patients. $^{13}$

Hyperuricemia increases morbidity and mortality among patients with diabetes. It results in a poor prognosis on the diabetic complications, correlated with increased prevalence of diabetic peripheral neuropathy, retinopathy and nephropathy. ${ }^{14}$ Hyperuricemia has been implicated in cardiovascular disease (CVD) through atherosclerotic processes. ${ }^{15}$ Hyperuricemia in T2DM is associated with the progression of diabetes and markers of CVD and is also a significant risk factor for coronary artery disease. ${ }^{16,17}$ Hyperuricemia in T2DM has been correlated with its complications. ${ }^{18}$ Another study showed that hyperuricemia was associated with the degree of renal damage in patients with T2DM, and complications of T2DM is more severe to those with hyperuricemia than normouricemia. Hyperuricemia can promote the progression and deterioration of renal diseases in T2DM patients. $^{19}$

DM is a disease condition which is rising alarmingly in both developing and developed countries, including Ethiopia. In Ethiopia, few studies have been conducted on the prevalence and determinants of hyperuricemia among type 2 diabetic patients. So, conducting this study is crucial to improving the early diagnosis and prevention of complications in diabetic patients. It will also lead to optimal care, improved quality of life, and reductions in morbidity and mortality among diabetic patients. This study is also important because if the prevalence of hyperuricemia is high among the diabetic population, it will help to form local guidelines. The findings of the study will also provide baseline data for researchers. Therefore, this study aimed to assess the prevalence and determinants of hyperuricemia among type 2 diabetic patients attending their follow-up at the chronic illness clinic of Jimma Medical Center (JMC).

\section{Materials and Methods Study Design, Area and Period}

The study was conducted at JMC from March 1 to June 30, 2019. The study was conducted on type 2 diabetic patients attending their follow-up at the chronic illness clinic of JMC. An institution-based cross-sectional design was used to carry out the study.

\section{Sample Size and Sampling Techniques}

A single population proportion formula was used to calculate the minimum sample size required using a $p$-value of 0.338 and $95 \%$ confidence interval $(\mathrm{CI}) .{ }^{20} \mathrm{~A}$ systematic random sampling technique was used. The $k$-value was calculated by dividing the total population by the sample size, giving a result of 6 , so data were collected from every sixth individual after a lottery method was employed for the first six patients on follow-up. The source population of this study was all type 2 diabetic patients who were attending their follow-up at the chronic illness clinic of JMC. The study population was all sampled type 2 diabetic patients who were attending follow-up at the chronic illness clinic and fulfilled the inclusion criteria. Type 2 diabetic patients with a history of gestational DM, treatment with statins or uricosuric drugs, or who had been diagnosed with malignancy (leukemia, lymphoma or myeloma) and were on chemotherapy were excluded from the study.

\section{Data Collection Procedures}

Interviewer-administered questionnaires were used to collect sociodemographic, clinical and behavior-related factors, as well as anthropometric data. Two diploma nurses with previous experience of data collection and multilingual ability were recruited for data collection. Training was given to data collectors prior to the data collection period to address the objective of the study. Continuous 
follow-up and supervision were provided by the supervisor and principal investigator throughout the data collection periods.

\section{Sample Collection and Processing}

After the required materials had been organized, consent was obtained from the study participants. The medial cubital vein was disinfected with $70 \%$ alcohol and a tourniquet was applied. Then, $5 \mathrm{~mL}$ of fasting overnight blood was collected from each participant by a trained health professional using aseptic/sterile technique. After the required amount of blood had been collected, the tourniquet was released. A dry gauze was placed over the vein puncture site, the needle was slowly withdrawn and the patient was asked to continue applying mild pressure. Contaminated supplies were properly disposed of and the tubes were labeled with the patient identification number and date. Gloves were removed and disposed of into the infectious labeled waste pit and hand washing was performed. ${ }^{21}$ The drawn sample was left for 30 minutes, then serum was separated from the collected blood sample by centrifugation at $3000 \mathrm{rpm}$ for 10 minutes using a Rotanta 960 centrifuge in a thermostable condition. Then, serum was taken and stored at $-20^{\circ} \mathrm{C}$ in the Biochemistry Laboratory of Jimma University until biochemical analysis took place.

\section{Laboratory Test Principles}

Serum UA content was determined using standard principles and procedures with an ABX Pentra 400 automated chemistry analyzer. UA is oxidized to allantoin and hydrogen peroxide by the enzyme uricase. In the presence of peroxidase, released hydrogen peroxide is coupled with aniline derivative and 4-amino antipyrine to form a colored chromogenic complex. The absorbance of the colored dye was measured at $520 \mathrm{~nm}$ and is proportional to the concentration of UA in the sample.

\section{Anthropometry and Blood Pressure Measurements}

Weight and height were measured according to the WHO guideline manual. ${ }^{33}$ Body weight was measured to an accuracy of $0.1 \mathrm{~kg}$ using portable weighing scales. Subjects were barefoot and wearing light indoor clothing. Body height without shoes was measured by a stadiometer. Body mass index (BMI) was calculated as the weight in kilograms divided by the square of the height in meters $\left[\mathrm{BMI}=\right.$ weight $\left./(\text { height })^{2} \mathrm{~kg} / \mathrm{m}^{2}\right]$. BMI
$<18.5,18.5-25,25-30$ and $>30 \mathrm{~kg} / \mathrm{m}^{2}$ were considered as underweight, normal, overweight and obesity, respectively. Waist circumference (WC) was measured after instructing each study subject to stand with their feet close together, arms at the side and body weight evenly distributed, wearing light clothes, at the midpoint between the lower margin of the least palpable rib and the top of the iliac crest, using stretch-resistant tape. The measurement was taken twice and average was taken when the difference between the two measurements was within $1 \mathrm{~cm}$. Repeated measurements were taken when the difference between the two measurements was greater than $1 \mathrm{~cm}$. Based on the WHO guideline manual of 2008 , a $\mathrm{WC}>80 \mathrm{~cm}$ and $>94 \mathrm{~cm}$ was considered abnormal for females and males, respectively. Hip circumference was measured at the widest part of the buttocks. ${ }^{22}$ Systolic blood pressure (SBP) and diastolic blood pressure (DBP) were measured from the left arm at the level of the heart using a mercury-based sphygmomanometer after the subjects had rested for more than 10 minutes, and 30 minutes after any consumption of a hot drink such as coffee. For those study subjects with SBP $\geq 140 \mathrm{mmHg}$ and DBP $\geq 90$ $\mathrm{mmHg}$, the blood pressure was measured again and the average value was taken. ${ }^{23}$

\section{Operational Definitions Hyperuricemia}

Hyperuricemia was defined as a serum UA level $>7.2 \mathrm{mg} / \mathrm{dL}$ for males and $>6 \mathrm{mg} / \mathrm{dL}$ for females.

\section{Increased Waist-Hip Ratio (WHR)}

Study participants who had a WHR $\geq 0.9$ for males and $\geq 0.85$ for females were considered to have an increased WHR.

\section{Alcohol Users}

An alcohol user was defined as a respondent who drank $>3-4$ units for males and $>2-3$ units for females daily at the start of the study.

\section{Hypertension}

Hypertension was defined as SBP $\geq 140 \mathrm{mmHg}$ or $\mathrm{DBP} \geq 90 \mathrm{mmHg}$.

\section{Data Quality Management and Statistical Analysis}

Before data analysis took place, all data from the questionnaires were checked manually for completeness and clarity. After that, data were entered into EpiData 
version 3.1 and then exported to IBM SPSS version 21 for analysis. Frequencies, proportions and means were computed to describe the relevant variables. The data output was presented using tables. A logistic regression model was computed to determine the association of independent variables and dependent variables. Bivariate analysis was carried out and those independent variables with $p$-values $<0.25$ were shifted into a multivariate logistic model. Finally, the significance of statistical associations was assured or tested using 95\% CIs and a $p$-value of $<0.05$ was considered significant in multivariable regression. Model fitness was also checked using the HosmerLemeshow test, with $p>0.05$.

\section{Results}

\section{Sociodemographic Characteristics of Study Participants}

A total of 287 study participants with T2DM on follow-up were enrolled in the study. The mean $\pm \mathrm{SD}$ age of the study participants was $51.79 \pm 14.36$ years, with a range of $20-85$ years. Among the total, $34.8 \%(n=100 / 287)$ of the study participants were in the age group $\geq 60$ years. The majority of the study participants, $65.9 \%(\mathrm{n}=189 / 287)$, were male and the rest were female. About $70 \%(n=201 / 287)$ of study participants were urban residents. Regarding their educational status, about $30.7 \%(n=88 / 287)$ of study participants identified that they had attended primary education and $37.6 \%(n=108 / 287)$ of study participants were government employees (Table 1).

\section{Clinical, Anthropometric and}

\section{Behavior-Related Characteristics of Study} Participants

The overall prevalence of hyperuricemia was $22 \%(n=63 /$ 287) among the study population. The mean BMI of study participants was $23.53 \pm 3.87 \mathrm{~kg} / \mathrm{m}^{2}$. The mean duration since diagnosis of diabetes was $8.68 \pm 6.5$ years, with the majority, $62.3 \%(n=179 / 287)$, having a duration of $<10$ years. About 33.79\% ( $\mathrm{n}=97 / 287)$ of the study participants had hypertension. The mean \pm SD blood pressure of study participants was $131.17 \pm 16.9 \mathrm{mmHg}$ for SBP and 84.89 $\pm 9.5 \mathrm{mmHg}$ for DBP. The mean $\pm \mathrm{SD}$ WC of the study participants was $81.95 \pm 21.4 \mathrm{~cm}$ and $113(39.4 \%)$ of them had an increased WC. The mean \pm SD WHR was 0.948 \pm 0.0713 and $243(84.7 \%)$ of them had an increased WHR (Table 2).
Table I Sociodemographic Information of Adult Type 2 DM patients on Chronic Follow-Up at JMC, Jimma, 2019

\begin{tabular}{|c|c|}
\hline Characteristic & Frequency $(\%)(\mathrm{N}=287)$ \\
\hline $\begin{array}{l}\text { Age group (years) } \\
\begin{array}{l}<40 \\
40-49 \\
50-59 \\
\geq 60\end{array}\end{array}$ & $\begin{array}{l}\text { Mean } \pm S D=51.79 \pm \mid 4.35, \text { range } \\
20-80 \\
65(22.65) \\
40(13.9) \\
82(28.6) \\
100(34.85)\end{array}$ \\
\hline $\begin{array}{l}\text { Educational status } \\
\text { No education } \\
\text { Only read and write } \\
\text { Primary education } \\
\text { Secondary education } \\
\text { Above secondary education }\end{array}$ & $\begin{array}{l}79(27.5) \\
6(2.1) \\
88(30.7) \\
47(16.4) \\
67(23.3)\end{array}$ \\
\hline $\begin{array}{l}\text { Marital status } \\
\text { Single } \\
\text { Married } \\
\text { Separated } \\
\text { Divorced } \\
\text { Widowed }\end{array}$ & $\begin{array}{l}21(7.3) \\
249(86.8) \\
5(1.7) \\
7(2.4) \\
5(1.7)\end{array}$ \\
\hline $\begin{array}{l}\text { Occupational status } \\
\text { Government employee } \\
\text { Merchant } \\
\text { Housewife } \\
\text { Farmer } \\
\text { Other }\end{array}$ & $\begin{array}{l}108(37.6) \\
92(32.1) \\
16(5.6) \\
51(17.8) \\
20(7)\end{array}$ \\
\hline $\begin{array}{l}\text { Place of residence } \\
\text { Rural } \\
\text { Urban }\end{array}$ & $\begin{array}{l}86(30) \\
201(70)\end{array}$ \\
\hline $\begin{array}{l}\text { Sex } \\
\qquad \text { Male } \\
\text { Female }\end{array}$ & $\begin{array}{l}189(65.9) \\
98(34.1)\end{array}$ \\
\hline
\end{tabular}

\section{Serum Uric Acid Levels of Study Participants According to Some Sociodemographic Characteristics}

About $42.8 \%(n=27)$ of study participants aged $\geq 60$ years had hyperuricemia. There was a high prevalence of hyperuricemia among males and urban residents (Table 3).

\section{Factors Associated with Hyperuricemia Among Study Participants}

According to statistical analysis, BMI $\geq 30 \mathrm{~kg} / \mathrm{m}^{2}$ (obesity), duration of $\mathrm{DM} \geq 10$ years, family history of CVD, alcohol drinking and increased DBP were independently associated with hyperuricemia. The study participants with obesity were 
Table 2 Clinical, Anthropometric and Behavior-Related Characteristics of Adult Type 2 DM Patients on Chronic Follow-Up at JMC, 2019

\begin{tabular}{|c|c|c|c|}
\hline Variable & Category & Frequency (\%) & \\
\hline BMI & $\begin{array}{l}\text { Underweight } \\
\text { Normal } \\
\text { Overweight } \\
\text { Obese }\end{array}$ & $\begin{array}{l}31(10.8) \\
154(53.7) \\
78(27.2) \\
24(8.3)\end{array}$ & Mean $\pm S D=23.53 \pm 3.87 \mathrm{~kg} / \mathrm{m}^{2}$, range $=14.6 \mathrm{I}-34.4 \mathrm{~kg} / \mathrm{m}^{2}$ \\
\hline WC & $\begin{array}{l}\text { Increased } \\
\text { Normal }\end{array}$ & $\begin{array}{l}\text { II } 3(39.4) \\
\text { I } 74(60.6)\end{array}$ & Mean $\pm S D=81.95 \pm 21.41 \mathrm{~cm}$, median $=89.0 \mathrm{~cm}$ \\
\hline WHR & $\begin{array}{l}\text { Increased } \\
\text { Normal }\end{array}$ & $\begin{array}{l}243(84.7) \\
44(15.3)\end{array}$ & Mean $\pm S D=0.948 \pm 0.07132$, Median $=0.950$ \\
\hline SBP & $\begin{array}{l}\text { Increased } \\
\text { Normal }\end{array}$ & $\begin{array}{l}53(18.5) \\
234(81.5)\end{array}$ & Mean $\pm S D=|3| . \mid 7 \pm 16.95 \mathrm{mmHg}$ \\
\hline DBP & $\begin{array}{l}\text { Increased } \\
\text { Normal }\end{array}$ & $\begin{array}{l}44(I 5.3) \\
243(84.3)\end{array}$ & Mean $\pm \mathrm{SD}=84.89 \pm 9.5 \mathrm{mmHg}$ \\
\hline FBS & $\begin{array}{l}\text { Increased } \\
\text { Normal }\end{array}$ & $\begin{array}{l}225(78.4) \\
62(21.6)\end{array}$ & Mean $\pm S D=178.12 \pm 56.9 \mathrm{mg} / \mathrm{dl}$ \\
\hline Duration of DM & $\begin{array}{l}\geq 10 \text { years } \\
<10 \text { years }\end{array}$ & $\begin{array}{l}108(37.63) \\
179(62.37)\end{array}$ & Mean $\pm S D=8.68 \pm 6.5$ years \\
\hline Family history of CVD & $\begin{array}{l}\text { Yes } \\
\text { No }\end{array}$ & $\begin{array}{l}28(9.8) \\
259(90.2)\end{array}$ & \\
\hline Smoking & $\begin{array}{l}\text { Yes } \\
\text { No }\end{array}$ & $\begin{array}{l}21(7.3) \\
266(89.5)\end{array}$ & \\
\hline Alcohol drinking & $\begin{array}{l}\text { Yes } \\
\text { No }\end{array}$ & $\begin{array}{l}34(I I .8) \\
253(88.2)\end{array}$ & \\
\hline Chat chewing & $\begin{array}{l}\text { Yes } \\
\text { No }\end{array}$ & $\begin{array}{l}\text { II } 139.37) \\
\text { I74 (60.62) }\end{array}$ & \\
\hline Physical activity & $\begin{array}{l}\text { Yes } \\
\text { No }\end{array}$ & $\begin{array}{l}187(65.15) \\
100(34.85)\end{array}$ & \\
\hline
\end{tabular}

7.84 times more likely ( $\mathrm{AOR}=7.84,95 \% \mathrm{CI}=2.005-30.666)$ to develop hyperuricemia compared with underweight individuals. Also, subjects with duration of $\mathrm{DM} \geq 10$ years were 3.963 times $(\mathrm{AOR}=3.963,95 \% \mathrm{CI}=1.902-8.259)$ more likely to develop hyperuricemia than those who had less than 10 years' duration of DM. The study participants who had increased DBP had were 4.198 times (AOR $=4.198,95 \%$ $\mathrm{CI}=1.772-9.949)$ more likely to develop hyperuricemia than those with normal DBP. Those participants with a history of alcohol consumption during the study period were about 5.83 times $(\mathrm{AOR}=5.83,95 \% \mathrm{CI}=2.341-14.545)$ more likely to develop hyperuricemia than those without a history of alcohol consumption. The study participants who had a family history of CVD were 2.929 times (AOR $=2.929$, 95\%
$\mathrm{CI}=1.124-7.630$ ) more likely to develop hyperuricemia than those who did not (Table 4).

\section{Discussion}

This study found that the prevalence of hyperuricemia was $22 \%$ among the study population. The finding was lower than the prevalence of hyperuricemia reported from Hawassa specialized hospital in Ethiopia, ${ }^{20}$ but the current finding of hyperuricemia was consistent with findings reported from Nairobi, Kenya, ${ }^{24}$ and from Puna, India. ${ }^{25}$ The prevalence of hyperuricemia reported from Lagos, Nigeria, was also comparable with the current finding. ${ }^{26}$ Disparity in the prevalence might be explained by different population profiles, such as dietary habits, geographical/environmental factors, 
Table 3 Serum Uric Acid Levels of Study Participants According to Some Sociodemographic Characteristics

\begin{tabular}{|c|c|c|c|c|}
\hline \multirow[t]{2}{*}{ Variable } & \multirow[t]{2}{*}{ Category } & \multicolumn{2}{|c|}{ Hyperuricemia } & \multirow[t]{2}{*}{$p$-Value } \\
\hline & & $\begin{array}{l}\text { Yes, } \\
\text { n (\%) } \\
(N=63)\end{array}$ & $\begin{array}{l}\text { No, n (\%) } \\
(\mathrm{N}=224))\end{array}$ & \\
\hline $\begin{array}{l}\text { Age } \\
\text { category } \\
\text { (years) }\end{array}$ & $\begin{array}{l}<40 \\
40-49 \\
50-59 \\
\geq 60\end{array}$ & $\begin{array}{l}9(14.3) \\
7(11.1) \\
20(31.74) \\
27(42.8)\end{array}$ & $\begin{array}{l}56(25) \\
33(14.73) \\
62(27.67) \\
73(32.59)\end{array}$ & 0.069 \\
\hline BMI & $\begin{array}{l}\text { Underweight } \\
\text { Normal } \\
\text { Overweight } \\
\text { Obese }\end{array}$ & $\begin{array}{l}6(9.52) \\
16(25.4) \\
27(42.86) \\
14(22.22)\end{array}$ & $\begin{array}{l}25(11.16) \\
138(61.6) \\
51(22.77) \\
10(4.5)\end{array}$ & 0.000 \\
\hline Sex & $\begin{array}{l}\text { Male } \\
\text { Female }\end{array}$ & $\begin{array}{l}39(61.9) \\
24(38.1)\end{array}$ & $\begin{array}{l}150(66.96) \\
74(33.03)\end{array}$ & 0.705 \\
\hline $\begin{array}{l}\text { Place of } \\
\text { residence }\end{array}$ & $\begin{array}{l}\text { Rural } \\
\text { Urban }\end{array}$ & $\begin{array}{l}\text { I8 (28.57) } \\
45(71.42)\end{array}$ & $\begin{array}{l}68(30.36) \\
156(69.64)\end{array}$ & 0.932 \\
\hline $\begin{array}{l}\text { Family } \\
\text { history of } \\
\text { CVD }\end{array}$ & $\begin{array}{l}\text { Yes } \\
\text { No }\end{array}$ & $\begin{array}{l}14(22.22) \\
49(77.78)\end{array}$ & $\begin{array}{l}14(6.25) \\
210(93.75)\end{array}$ & 0.000 \\
\hline WC & $\begin{array}{l}\text { Increased } \\
\text { Normal }\end{array}$ & $\begin{array}{l}27(42.86) \\
36(57.14)\end{array}$ & $\begin{array}{l}86(38.4) \\
138(61.6)\end{array}$ & 0.143 \\
\hline WHR & $\begin{array}{l}\text { Increased } \\
\text { Normal }\end{array}$ & $\begin{array}{l}58(92.06) \\
5(7.94)\end{array}$ & $\begin{array}{l}185(82.59) \\
39(17.4 I)\end{array}$ & 0.153 \\
\hline SBP & $\begin{array}{l}\text { Normal } \\
\text { Hypertensive }\end{array}$ & $\begin{array}{l}42(66.67) \\
21(33.3)\end{array}$ & $\begin{array}{l}192(85.7) \\
32(14.3)\end{array}$ & 0.003 \\
\hline
\end{tabular}

genetic factors, sample size, study design and the use of different cut-off values. ${ }^{20,25,26}$

This study found that duration of $\mathrm{DM} \geq 10$ years, obesity, increased DBP, family history of CVD and alcohol drinking were significantly associated with hyperuricemia (Table 4). The study participants who had a history of alcohol drinking were 5.83 times more likely to develop hyperuricemia than those who did not have a history of drinking alcohol. Similarly, the study from Hawassa found that study subjects with a history of alcohol consumption during the study period were about 1.6 times more likely to develop hyperuricemia, ${ }^{20}$ which was in line with this study. This may be due to alcohol consumption resulting in increased urate production and also inducing hyperlacticacidemia, which reduces UA excretion. ${ }^{27}$

The study revealed that patients with duration of $\mathrm{DM} \geq 10$ years were 3.96 times more likely to develop hyperuricemia than those who had $<10$ years' duration of DM. This finding is supported by a study conducted in India, which found that the mean UA level increased with duration of DM. ${ }^{14}$ This may be because, during the later stages of DM, elevation of UA acts as a pro-oxidant that results in chronic complications such as atherosclerosis. $^{15}$

Also, in this study it was found that obesity was significantly associated with hyperuricemia. This finding was in agreement with a study conducted in Sudan, which showed that hyperuricemia was significantly positively correlated with BMI. ${ }^{28}$ This may be due to insulin resistance caused by obesity being associated with hyperuricemia. ${ }^{29}$

Study subjects who had increased DBP had a 4.2 times greater chance of developing hyperuricemia than those with normal DBP. This finding is supported by a study conducted in Iran showing that serum UA had a strong association with DBP in type 2 diabetic patients. ${ }^{30}$ This may be due to UA uptake into vascular smooth muscle leading to cellular proliferation and secondary atherosclerosis, which impairs pressure natriuresis. ${ }^{31}$

This study also revealed that participants who had a family history of CVD were 2.929 times more likely to develop hyperuricemia than who did not have a family history of CVD. Even though no studies have been conducted to show the association between family history of CVD and hyperuricemia among T2DM patients, a family history of CVD modifies the future CVD risk depending on the number and age of affected first degree relatives. ${ }^{32}$

\section{Conclusion}

The prevalence of hyperuricemia was relatively high in type 2 diabetic patients. Hyperuricemia was significantly associated with obesity, duration of $\mathrm{DM} \geq 10$ years, having a family history of CVD, alcohol drinking and increased DBP.

\section{Recommendations}

Based on the findings from the study, the following recommendations were forwarded to the respective responsible bodies to reduce diabetes-related complications among patients with T2DM due to hyperuricemia. Health professionals and other stakeholders are recommended to give regular health information about lifestyle modification, early diagnosis and treatment of hyperuricemia in type 2 diabetic patients, to perform regular screening for serum UA levels, and pay due attention to policies that enable screening for UA in T2DM and increase awareness on risk factor reduction. Further studies need to be conducted with larger numbers of patients with diabetes to determine the factors associated with impairment of serum UA. 
Table 4 Bivariate and Multivariable Binary Logistic Regression for Hyperuricemia of Adult Type 2 DM Patients on Chronic Follow-Up at JMC, 2019

\begin{tabular}{|c|c|c|c|c|c|}
\hline \multirow[t]{2}{*}{ Variable } & \multirow[t]{2}{*}{ Category } & \multicolumn{2}{|c|}{ Hyperuricemia } & \multirow[t]{2}{*}{ COR $(95 \% \mathrm{Cl})$} & \multirow[t]{2}{*}{ AOR $(95 \% \mathrm{Cl})$} \\
\hline & & Yes $(\mathrm{N}=63)$ & No $(N=224)$ & & \\
\hline Age (years) & $\begin{array}{l}<40 \\
40-49 \\
50-59 \\
\geq 60\end{array}$ & $\begin{array}{l}9 \\
7 \\
20 \\
27\end{array}$ & $\begin{array}{l}56 \\
33 \\
62 \\
73\end{array}$ & $\begin{array}{l}\text { I } \\
1.320(0.449-3.876) \\
2.007(0.845-4.770) \\
2.301(1.003-5.282)^{*}\end{array}$ & $\begin{array}{l}\text { I } \\
0.627(0.15 I-2.609) \\
\text { I.265 (0.445-3.595) } \\
2.073(0.739-5.816)\end{array}$ \\
\hline BMI & $\begin{array}{l}\text { Underweight } \\
\text { Normal } \\
\text { Overweight } \\
\text { Obese }\end{array}$ & $\begin{array}{l}6 \\
20 \\
37 \\
14\end{array}$ & $\begin{array}{l}25 \\
141 \\
48 \\
10\end{array}$ & $\begin{array}{l}\text { I } \\
0.483(0.172-1.354) \\
2.206(0.807-6.031) \\
5.833(1.748-19.468)^{*}\end{array}$ & $\begin{array}{l}\text { I } \\
0.596(0.193-1.842) \\
1.905(0.623-5.824) \\
7.84(2.005-30.666)^{* *}\end{array}$ \\
\hline Duration of DM & $\begin{array}{l}<10 \\
\geq 10\end{array}$ & $\begin{array}{l}23 \\
40\end{array}$ & $\begin{array}{l}156 \\
68\end{array}$ & $\begin{array}{l}\text { I } \\
3.99(2.219-7.174)^{*}\end{array}$ & $\begin{array}{l}\text { I } \\
3.963(1.902-8.259)^{* *}\end{array}$ \\
\hline Family History of CVD & $\begin{array}{l}\text { Yes } \\
\text { No }\end{array}$ & $\begin{array}{l}14 \\
49\end{array}$ & $\begin{array}{l}14 \\
210\end{array}$ & $\begin{array}{l}4.286(1.919-9.57 \mid)^{*} \\
I\end{array}$ & $\begin{array}{l}2.929(1.124-7.630)^{* *} \\
\mathrm{I}\end{array}$ \\
\hline SBP & $\begin{array}{l}\text { Normal } \\
\text { Increased }\end{array}$ & $\begin{array}{l}42 \\
21\end{array}$ & $\begin{array}{l}192 \\
32\end{array}$ & $\begin{array}{l}\text { I } \\
3.0(1.576-5.711)^{*}\end{array}$ & $\begin{array}{l}\text { I } \\
\text { I.679 (0.707-3.987) }\end{array}$ \\
\hline DBP & $\begin{array}{l}\text { Normal } \\
\text { Increased }\end{array}$ & $\begin{array}{l}48 \\
15\end{array}$ & $\begin{array}{l}195 \\
29\end{array}$ & $\begin{array}{l}\text { I } \\
2.101(1.045-4.226)^{*}\end{array}$ & $\begin{array}{l}\text { I } \\
4.198(1.772-9.949)^{* *}\end{array}$ \\
\hline Cigarette smoking & $\begin{array}{l}\text { Yes } \\
\text { No }\end{array}$ & $\begin{array}{l}15 \\
48\end{array}$ & $\begin{array}{l}6 \\
218\end{array}$ & II.354 (4.190-30.77)* & $\begin{array}{l}3.074(0.740-12.763) \\
\text { I }\end{array}$ \\
\hline Alcohol drinking & $\begin{array}{l}\text { Yes } \\
\text { No }\end{array}$ & $\begin{array}{l}20 \\
43\end{array}$ & $\begin{array}{l}14 \\
210\end{array}$ & $\begin{array}{l}6.977(3.270-14.884)^{*} \\
\text { I }\end{array}$ & $\begin{array}{l}5.83(2.34|-| 4.545)^{* *} \\
I\end{array}$ \\
\hline WHR & $\begin{array}{l}\text { Normal } \\
\text { Increased }\end{array}$ & $\begin{array}{l}5 \\
58\end{array}$ & $\begin{array}{l}39 \\
185\end{array}$ & $\begin{array}{l}\text { I } \\
2.445(0.921-6.494)\end{array}$ & $\begin{array}{l}\text { I } \\
0.798(0.254-2.501)\end{array}$ \\
\hline Chat chewing & $\begin{array}{l}\text { Yes } \\
\text { No }\end{array}$ & $\begin{array}{l}31 \\
32\end{array}$ & $\begin{array}{l}82 \\
142\end{array}$ & $\begin{array}{l}\text { I.678 (0.955-2.948) } \\
\text { । }\end{array}$ & $\begin{array}{l}1.475(0.690-3.154) \\
\text { । }\end{array}$ \\
\hline
\end{tabular}

Note: $* p<0.05, * * p<0.01$.

Abbreviations: COR, crude odds ratio; AOR, adjusted odds ratio.

\section{Limitations of the Study}

Despite the fact that the necessary endeavors were made to minimize or avoid possible limitations of the study, the results should be interpreted in the light of the following unavoidable limitations. This was a singlecenter study with a relatively small sample size, so these results may not be generalizable to the entire population of patients with T2DM in Ethiopia. Owing to resource limitations, the HOMA test was not performed to determine the status of insulin resistance, and the concentration of insulin was not measured. This was a cross-sectional study; hence, no causal inferences or temporal associations could be drawn because the study design describes only what is happening at the present time.

\section{Abbreviations}

AOR, adjusted odds ratio; COR, crude odds ratio; CVD, cardiovascular disease; DBP, diastolic blood pressure; $\mathrm{DM}$, diabetes mellitus; FBS, fasting blood sugar; $\mathrm{HbA}_{1 \mathrm{C}}$, glycated hemoglobin $\mathrm{A}_{1 \mathrm{C}}$; JMC, Jimma Medical Center; SBP, systolic blood pressure; SD, standard deviation; T2DM, type 2 diabetes mellitus; UA, uric acid; WC, waist circumference; WHO, World Health Organization; WHR, waist-hip ratio.

\section{Ethical Considerations}

The study was approved by and ethical clearance was obtained from Jimma University institutional review board. An official letter of permission was obtained from Jimma Institute of Health ethical review board and given to the Jimma Medical 
Center director's office to conduct the study. Selected respondents were well informed about the purpose, benefits and methods of the study. Study participants were also informed that they could withdraw from the study at any time and that withdrawal would have no negative impact on their diagnosis and treatment in the hospital. Information was collected after informed consent had been obtained from each participant. Information was recorded anonymously and confidentiality and beneficence were assured throughout the study period. The study was conducted in accordance with the Declaration of Helsinki.

\section{Acknowledgments}

We would like to thank Jimma University for funding this study and JMC staff for their cooperation while conducting this study. Also, we would like to convey heartfelt gratitude to the study participants for their kind and unlimited cooperation, support and participation in the study.

\section{Disclosure}

The authors report there are no conflicts of interest in this work.

\section{References}

1. American Diabetes Association. Diagnosis and classification of diabetes mellitus. Diabetes Care. 2013;36(SUPPL.1):67-74. doi:10.23 37/dc13-S067

2. World Health Organization. Definition and Diagnosis of Diabetes Mellitus and Intermediate Hyperglycemia. Vol. 3; 2006.

3. Goldenberg R. Definition, classification and diagnosis of diabetes, prediabetes and metabolic syndrome. Can J Diabetes. 2013;37 (S):8-11. doi:10.1016/j.jcjd.2013.01.011

4. American Diabetes Association. Screening for type 2 diabetes. Diabetes Care. 1998;21(SUPPL. 1):1997-1999. doi:10.2337/diacare.21.1.S83

5. Kaku K. Pathophysiology of type 2 diabetes and its treatment policy. JMAJ. 2010;138(1):41-46.

6. Glantzounis GK, Tsimoyiannis EC, Kappas AM, Galaris DA. Uric acid and oxidative stress. Curr Pharm Des. 2005;11(32):4145-4151. doi:10.2174/138161205774913255

7. Bardin T, Richette P. Definition of hyperuricemia and gouty conditions. Curr Opin Rheumatol. 2014;26(2):186-191. doi:10.10 97/BOR.0000000000000028

8. Oda M, Satta Y, Takenaka O, Takahata N. Loss of urate oxidase activity in hominoids and its evolutionary implications. Mol Biol Evol. 2001;19 (5):640-653. doi:10.1093/oxfordjournals.molbev.a004123

9. Grassi D, Ferri L, Desideri G, et al. Chronic hyperuricemia, uric acid deposit and cardiovascular risk. Curr Pharm Des. 2013;19 (13):2432-2438. doi:10.2174/1381612811319130011

10. Strazzullo P, Puig J. Uric acid and oxidative stress: relative impact on cardiovascular risk. Nutr Metab Cardiovasc Dis. 2007;17(6):409-414. doi:10.1016/j.numecd.2007.02.011

11. Corry DB, Eslami P, Yamamoto K, Nyby MD, Makino H, Tuck ML. Uric acid stimulates vascular smooth muscle cell proliferation and oxidative stress via the vascular renin - angiotensin system. J Hypertens. 2008;26(2):269-275. doi:10.1097/HJH.0b013e3282f240bf
12. Sautin YY, Johnson RJ, Sautin YY, Johnson RJ. Uric acid: the oxidant-antioxidant paradox uric acid. Nucleosides Nucleotides Nucleic Acids. 2008;27(6-7):608-619. doi:10.1080/15257770802138558

13. Shah P, Bjornstad P, Johnson RJ. Hyperuricemia as a potential risk factor for type 2 diabetes and diabetic nephropathy. Brazilian Journal of Nephrology. 2016;38(4):386-387. doi:10.5935/0101-2800.20160061

14. Rao TMV, Vanukuri NK. A study on serum uric acid levels in type 2 diabetes mellitus and its association with cardiovascular risk factors. IAIM. 2016;3(12):148-155.

15. So A, Thorens B. Uric acid transport and disease. J Clin Invest. 2010;120(6):1791-1799. doi:10.1172/JCI42344

16. Agarwal AK, Singh M, Arya V, Garga U, Singh VP, Jain V. Prevalence of peripheral arterial disease in type 2 diabetes mellitus and its correlation with coronary artery disease and its risk factors. $J$ Assoc Physicians India. 2012;60(7):28-32.

17. Khare S, Vishandasani JK, Kansal A. To study serum uric acid in type 2 diabetes mellitus patient. IOSR J Dent Med Sci. 2015;14(9):82-86.

18. muruganandam U, Maniappan M, Manshur M. Study of impact of serum uric acid in type 2 diabetic patients and its relationship with development of complications. IOSR J Dent Med Sci. 2017;16 (3):58-62. doi:10.9790/0853-1603055862

19. Li G, Jiao X, Cheng X. Correlations between blood uric acid and the incidence and progression of type 2 diabetes nephropathy. Eur Rev Med Pharmacol Sci. 2018;22:506-511.

20. Woyesa SB, Hirigo AT, Wube TB. Hyperuricemia and metabolic syndrome in type 2 diabetes mellitus patients at Hawassa university comprehensive specialized hospital, South West Ethiopia. BMC Endocr Disord. 2017;17(76):1-8. doi:10.1186/s12902-017-0226-y

21. World Health Organization. WHO Guidelines on Drawing Blood: Best Practices in Phlebotomy; 2010.

22. World Health Organization. Waist Circumference and Waist-Hip Ratio Report of a WHO Expert Consultation. Geneva; 2008.

23. Ogedegbe G, Pickering T. Principles and techniques of blood pressure measurement. Cardiol Clin. 2013;28(4):571-586. doi:10.1016/j. ccl.2010.07.006

24. Mufaddal S. Serum Uric Acid Levels in Patients With Type 2 Diabetes at Kenyatta National Hospital. Jmaj. 2018.

25. Mundhe SA, Mhasde DR. The study of prevalence of hyperuricemia and metabolic syndrome in type 2 diabetes mellitus. Int J Adv Med. 2016;3(2):241-249. doi:10.18203/2349-3933.ijam20160655

26. Ogbera AO, Azenabor AO. Hyperuricaemia and the metabolic syndrome in type 2 DM. Diabetol Metab Syndr. 2010;2(4):1-7. doi:10.1186/1758-5996-2-1

27. Seki S, Oki Y, Tsunoda S, Takemoto T, Koyama T, Yoshimura M. Impact of alcohol intake on the relationships of uric acid with blood pressure and cardiac hypertrophy in essential hypertension. J Cardiol. 2016;68(5):447-454. doi:10.1016/j.jjcc.2015.11.006

28. Em I, Elbadawi N, Hassan D. Uric acid as a biomarker of metabolic syndrome in Sudanese Adults. Int J Biochem Physiol. 2018;61:1-7.

29. Han T, Meng X, Shan R, et al. Temporal relationship between hyperuricemia and obesity, and its association with future risk of type 2 diabetes. Int $J$ Obes. 2018;42(7):1336-1344. doi:10.1038/ s41366-018-0074-5

30. Rafieian-kopaei M, Behradmanesh S, Kheiri S, Nasri H. Association of serum uric acid with level of blood pressure in type 2 diabetic patients. Int J Kidney Dis. 2014;8(2):152-154.

31. Feig DI. Hyperuricemia and hypertension. Adv Chronic Kidney Dis. 2012;19(6):377-385. doi:10.1053/j.ackd.2012.05.009

32. Kolber MR. Family history of cardiovascular disease. Can Fam Physician. 2014;60:1016.

33. World Health Organization. STEPwise approach to surveillance (STEPS), STEPS Instrument. Available from: https://www.who.int/ ncds/surveillance/steps/instrument/en/. Accessed June 8, 2020. 


\section{Publish your work in this journal}

Diabetes, Metabolic Syndrome and Obesity: Targets and Therapy is an international, peer-reviewed open-access journal committed to the rapid publication of the latest laboratory and clinical findings in the fields of diabetes, metabolic syndrome and obesity research. Original research, review, case reports, hypothesis formation, expert opinion and commentaries are all considered for publication. The manuscript management system is completely online and includes a very quick and fair peer-review system, which is all easy to use. Visit http://www.dovepress.com/testimonials.php to read real quotes from published authors. 